\title{
Mapping of Research Productivity in Lovely Professional University: A Scientometric Study
}

\author{
R. Senthilkumar ${ }^{1 *}$ and G. Ulaganathan ${ }^{2}$ \\ 'Librarian (SG) and Head (Research), Department of Library and Information Science, Kongunadu Arts and Science \\ College (Autonomous), Coimbatore - 641029, Tamil Nadu, India \\ 2LIS, Research Scholar PhD (PT), Kongunadu Arts and Science College (Autonomous), Coimbatore - 641029, \\ Tamil Nadu, India
}

\begin{abstract}
This paper discusses about the published research articles and its citation available in the Indian Citation Index by the authors from Lovely Professional University. The relevant data are collected from Indian Citation Index and it was analyzed. It shows among the published. 387 articles, maximum of 148 (38.24\%) articles published in 2015 and minimum $1(0.26 \%)$ article published in 2007. Based on the citation study during the period 86 citations were made. Among the Citations, maximum of 20 (23.26\%) citations in 2010 and 2015 followed by 19 (22.09\%) citations in 2012 was identified.
\end{abstract}

Keywords: Citation Analysis, Lovely Professional University, Mapping, Research Productivity ICI, Scientometric, Year Wise Distribution

\section{Introduction}

The true barometer of assessing the quality and quantity of a journal is the Citation Index. While discussing citation, one needs to understand the citation. Simply, when another refers other works in his/her article, we call the article referred is cited. In other words the citation is called as the previous work which is referred in the present work. The quality of a given work can rightly be adjudged through the number of citations that it gets. Therefore, a certain piece of article or research paper is carrying more number of citations get more impact than the work carrying fewer citations. Therefore, we always refer to some indexing and abstracting databases like Scopus, Web of Science, or even Google Scholars to know the impact of a journal, a particular article or a particular author. Indian Citation Index which was initiated by Diva Enterprises is just an indexing and abstracting database.

\section{Review of Literature}

Nicholas and Ritchie [1] view that, "bibliometric studies provide information about the structure of knowledge and how it is communicated" Moreover, bibliometric studies are normally employed to evaluate the academic research output, the quality of the journal, impact and influence of articles, authors, and assorted parameters. Though there has been substantial growth of literature on bibliometric studies during the last decade, the authors focus on some of the pertinent literature that relate to the present study. Potter [2] defines bibliometric study as "the study and measurement of the publication patterns of all forms of written communication and their authorship". In a most interesting study Mooghali [3] et al., analyzed records of three premiere indexes namely, "Social Science Citation Index", "Science Citation Index", and "Arts and Humanities Citation Index", and projected how the field of "scientometrics" evolved between 1980 to 2009. The pattern of growth of literature in the field of Nanoscience

${ }^{*}$ Author for correspondence 
during 1990 to 2009 was reported by Karpagam et al, [4]. In the similar vein, Abramo [5] exercised bibliometric techniques on some national level research assessments. Lapon-Kandeishein and Prebor [6] have done their bibliographical research on Hebrew printing also needs mention. In the similar light bibliometric studies by veterans like Krampen, Eye and Schui [7], Kumar Suchetan [8] and others also presented findings on different directions. Dhanavandan and Tamizhchelvan [9] studied research productivity and citations of universities in south Tamil Nadu from 2009 to 2013 which is based on Indian Citation Index.

\section{Methodology}

"This study aims to discuss about the analysis of the citation index of the research output by faculty members of Lovely Professional University [10]. The relevant sources and data are collected from Indian Citation Index. Based on the available sources the following discussions are made."

\section{Analysis and Interpretation}

The distributions of the research output by the authors from Lovely Professional University that are available in Indian Citation Index were analyzed in the Table 1.

\section{Year Wise Distribution of Published Articles Vs Citations}

Table 1. Year Wise Distribution of Published Articles Vs Citations

\begin{tabular}{|c|c|c|c|c|c|c|c|}
\hline S.No. & Year & Articles & $\%$ & Citation & $\%$ & $\begin{array}{c}\text { Citation } \\
\text { Density }\end{array}$ & $\begin{array}{c}\text { Article/ } \\
\text { Citation }\end{array}$ \\
\hline 1 & 2007 & 1 & 0.26 & 1 & 1.16 & 1.000 & 1 \\
\hline 2 & 2008 & 4 & 1.03 & 0 & 0 & 0.000 & N/A \\
\hline 3 & 2009 & 14 & 3.62 & 2 & 2.32 & 0.143 & 7 \\
\hline 4 & 2010 & 23 & 5.94 & 20 & 23.26 & 0.870 & 1 \\
\hline 5 & 2011 & 24 & 6.20 & 5 & 5.81 & 0.208 & 5 \\
\hline 6 & 2012 & 51 & 13.18 & 19 & 22.09 & 0.373 & 3 \\
\hline 7 & 2013 & 57 & 14.73 & 9 & 10.47 & 0.158 & 6 \\
\hline 8 & 2014 & 65 & 16.80 & 10 & 11.63 & 0.154 & 7 \\
\hline 9 & 2015 & 148 & 38.24 & 20 & 23.26 & 0.135 & 7 \\
\hline & Total & 387 & 100 & 86 & 100 & 3.041 & 37 \\
\hline
\end{tabular}

The above Table shows that the year wise distribution of articles published by the various authors from Lovely Professional University. From 2007 to 2015, 387 articles were published which are indexed in Indian Citation Index. Among the 387, maximum of 148 (38.24\%) articles published in 2015 and minimum 1 (0.26\%) article published in 2007. Based on the citation during the period 86 citations were made. Among the 86 Citations, maximum of $20(23.26 \%)$ citations in 2010 and 2015 followed by 19 (22.09\%) citations in 2012 was identified.

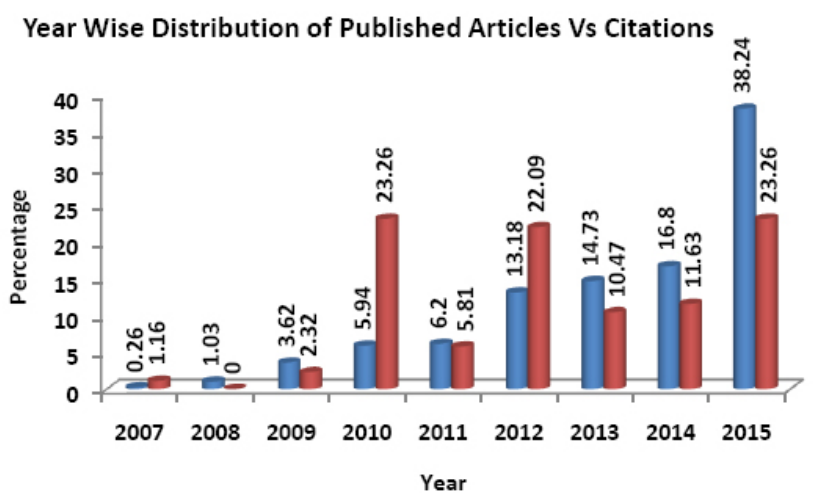

Table 2. Year wise distribution of cited articles and cited density

\begin{tabular}{|c|c|c|c|c|c|}
\hline S. No. & Year & $\begin{array}{c}\text { Cited } \\
\text { Articles }\end{array}$ & $\%$ & $\begin{array}{c}\text { Cited } \\
\text { Density }\end{array}$ & $\begin{array}{c}\text { Article/Cited } \\
\text { Articles }\end{array}$ \\
\hline 1 & 2007 & 1 & 2.04 & 1.000 & 1.000 \\
\hline 2 & 2008 & 0 & 0 & 0.0 & 0.000 \\
\hline 3 & 2009 & 2 & 4.08 & 0.143 & 7.000 \\
\hline 4 & 2010 & 5 & 10.21 & 0.217 & 4.600 \\
\hline 5 & 2011 & 2 & 4.08 & 0.083 & 12.000 \\
\hline 6 & 2012 & 10 & 20.41 & 0.196 & 5.100 \\
\hline 7 & 2013 & 6 & 12.24 & 0.105 & 9.500 \\
\hline 8 & 2014 & 8 & 16.33 & 0.123 & 8.125 \\
\hline 9 & 2015 & 15 & 30.61 & 0.101 & 9.867 \\
\hline & Total & 49 & 100 & 1.968 & 57.192 \\
\hline
\end{tabular}

The above Table presents the year wise distribution of Cited articles, Cited density and Article/Cited articles published by the various authors from Lovely Professional University. From 2007 to 2015, 49 cited articles were available which are indexed in Indian Citation Index. Among the cited articles maximum of $15(30.61 \%)$ in 2015 followed by $10(20.41 \%)$ cited articles in 2012. Based on the cited density during the period maximum of 1 in 2007 and followed by 0.217 in 2010, was identified. 
Year Wise Distribution of Cited Articles \%

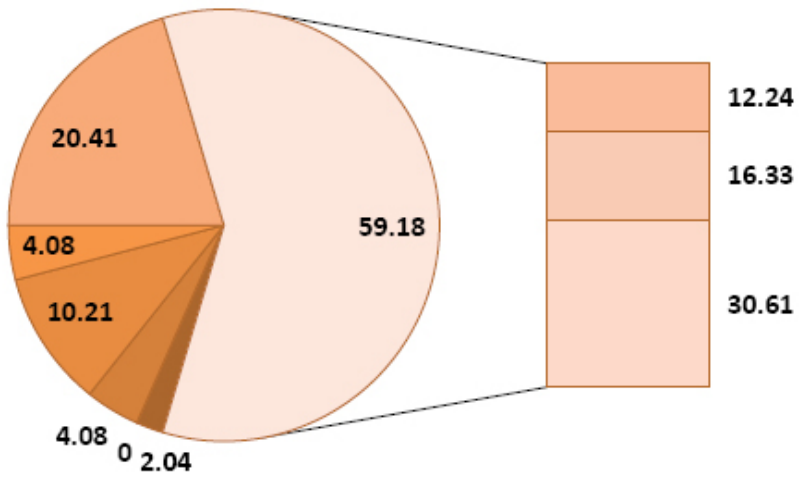

Table 3. Author-wise distribution of articles and citations (Top 15)

\begin{tabular}{|c|c|c|c|c|}
\hline S.No. & Author & Articles & Citation & $\begin{array}{c}\text { Citation } \\
\text { Density }\end{array}$ \\
\hline 1 & Prasad Dwarika & 15 & 3 & 0.200 \\
\hline 2 & Kumar Ashish & 14 & 3 & 0.214 \\
\hline 3 & Kumar Arun & 10 & 1 & 0.100 \\
\hline 4 & Gupta Monika & 10 & 2 & 0.200 \\
\hline 5 & Thakur R C & 9 & 1 & 0.111 \\
\hline 6 & Singh Joginder & 8 & 1 & 0.125 \\
\hline 7 & Singh Harminder & 8 & 1 & 0.125 \\
\hline 8 & Gupta Sudhakar & 8 & 2 & 0.250 \\
\hline 9 & Kaur Loveleen & 7 & 0 & 0.000 \\
\hline 10 & Bhople Balkrishna & 7 & 1 & 0.143 \\
\hline 11 & Sopan & 7 & 7 & 1.000 \\
\hline 12 & Venkadesan R & 7 & 0 & 0.000 \\
\hline 13 & Sharma Ravi & 6 & 0 & 0.000 \\
\hline 14 & Tanwar Beenu & 6 & 0 & 0.000 \\
\hline 15 & Singh Simranjeet & 6 & 4 & 0.667 \\
\hline & Total & 128 & 26 & 3.135 \\
\hline
\end{tabular}

The above table reveals that the author wise distribution of the articles published and citations are available in the Indian Citation Index. Only we consider in the top fifteen authors. Among the 15, Prasad Dwarika occupied the first position with 15 articles and 3 citations followed by author Kumar Ashish in the second position with 14 articles and 3 citations and Kumar Arun in the third position with 10 articles and 1 citation (Ranked by Articles only). In the case of highest citations Pramanik Tanay is in the first position with 7 citations and Singh Simranjeet occupies the second position with 4 citations

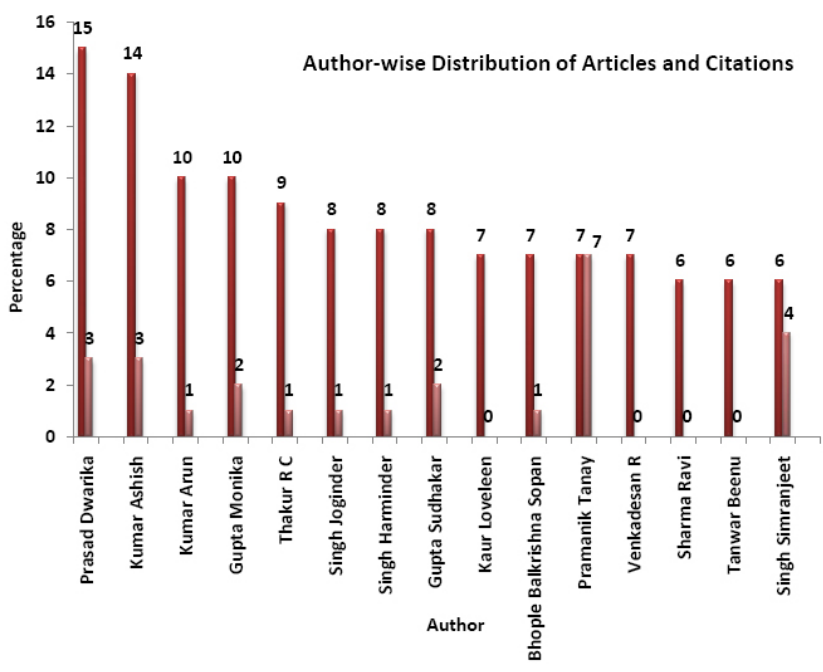

Table 4. Subject wise distribution of cited articles (TOP 15)

\begin{tabular}{|c|c|c|c|}
\hline S.No. & Subject Category & Articles & Citation \\
\hline 1 & $\begin{array}{c}\text { Pharmacology and Pharmaceutical } \\
\text { Science }\end{array}$ & 140 & 42 \\
\hline 2 & Chemistry & 116 & 25 \\
\hline 3 & Biological Science & 95 & 8 \\
\hline 4 & Health Science & 53 & 26 \\
\hline 5 & Engineering Science and Technology & 34 & 2 \\
\hline 6 & General Science and Technology & 32 & 9 \\
\hline 7 & Management & 30 & 2 \\
\hline 8 & Biotechnology & 19 & 3 \\
\hline 9 & Business and Marketing & 17 & 3 \\
\hline 10 & Environmental Science & 16 & 2 \\
\hline 11 & Computer Science and Technology & 16 & 0 \\
\hline 12 & Social Science & 12 & 0 \\
\hline 13 & Arts and Humanities & 11 & 0 \\
\hline 14 & Education & 9 & 0 \\
\hline 15 & Economics & 9 & 1 \\
\hline & Total & 609 & 56 \\
\hline
\end{tabular}

The above Table presents the top 15 subjects it includes various articles published and cited from the Lovely Professional University that are available in the Indian Citation Index. "As per the sources available in the Indian Citation Index. Among the articles 140 from Pharmacology and Pharmaceutical Science is in the first rank, 116 articles from Chemistry with second rank and 95 articles from Biological Science subject in third rank were 
identified. It is revealed from the table that Pharmacology and Pharmaceutical Science subject has the highest citations 42 when comparing to other subjects".

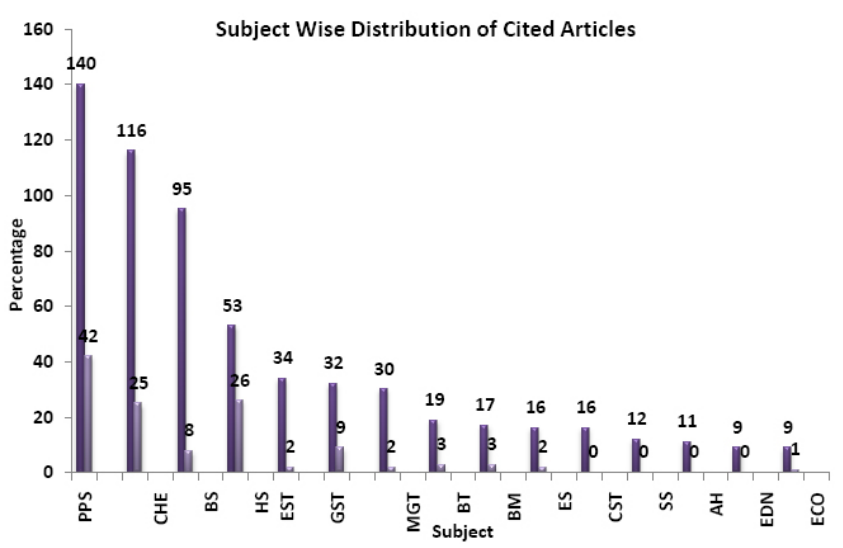

Table 5. Distribution of top 15 cited journals

\begin{tabular}{|c|c|c|c|}
\hline S.No. & Publications & Articles & Citation \\
\hline 1 & $\begin{array}{c}\text { Research Journal of Pharmaceutical, } \\
\text { Biological, and Chemical Sciences }\end{array}$ & 57 & 6 \\
\hline 2 & $\begin{array}{c}\text { Journal of Chemical and } \\
\text { Pharmaceutical Research }\end{array}$ & 36 & 5 \\
\hline 3 & Oriental Journal of Chemistry & 28 & 11 \\
\hline 4 & $\begin{array}{c}\text { Indian Journal of Science and } \\
\text { Technology }\end{array}$ & 24 & 8 \\
\hline 5 & $\begin{array}{c}\text { Indian Journal of Physiotherapy and } \\
\text { Occupational Therapy }\end{array}$ & 18 & 0 \\
\hline 6 & $\begin{array}{c}\text { Biosciences, Biotechnology Research } \\
\text { Asia }\end{array}$ & 12 & 1 \\
\hline 7 & $\begin{array}{c}\text { Asian Journal of Research in Business } \\
\text { Economics and Management }\end{array}$ & 11 & 0 \\
\hline 8 & $\begin{array}{c}\text { International Journal of Pharmacy } \\
\text { and Pharmaceutical Sciences }\end{array}$ & 11 & 3 \\
\hline 9 & $\begin{array}{c}\text { The Criterion: An International } \\
\text { Journal in English }\end{array}$ & 11 & 0 \\
\hline 10 & $\begin{array}{c}\text { International Journal of Drug } \\
\text { Development and Research }\end{array}$ & 10 & 14 \\
\hline 11 & $\begin{array}{c}\text { International Journal of Chemtech } \\
\text { Research }\end{array}$ & 9 & 0 \\
\hline 12 & $\begin{array}{c}\text { International Journal of Engineering } \\
\text { Science and Technology }\end{array}$ & 9 & 1 \\
\hline Asian Journal of Pharmaceutical \& \\
\hline 15 & $\begin{array}{c}\text { Edinical Research } \\
\text { Journal of Education ad Applied }\end{array}$ & 7 & 0 \\
\hline
\end{tabular}

The data presented in the above table shows the top 15 journals articles published and cited by authors in Lovely Professional University. Among the top 15, Research Journal of Pharmaceutical, Biological, and Chemical Sciences occupies the first place with 57 articles the second place in Journal of Chemical and Pharmaceutical Research with 36 articles and the third place in Oriental Journal of Chemistry with 28 articles publications. Based on the citation International Journal of Drug Development and Research occupies the first position with 14 citations and Oriental Journal of Chemistry is in the second position with 12 citations.

\section{Distribution of Cited Journals}

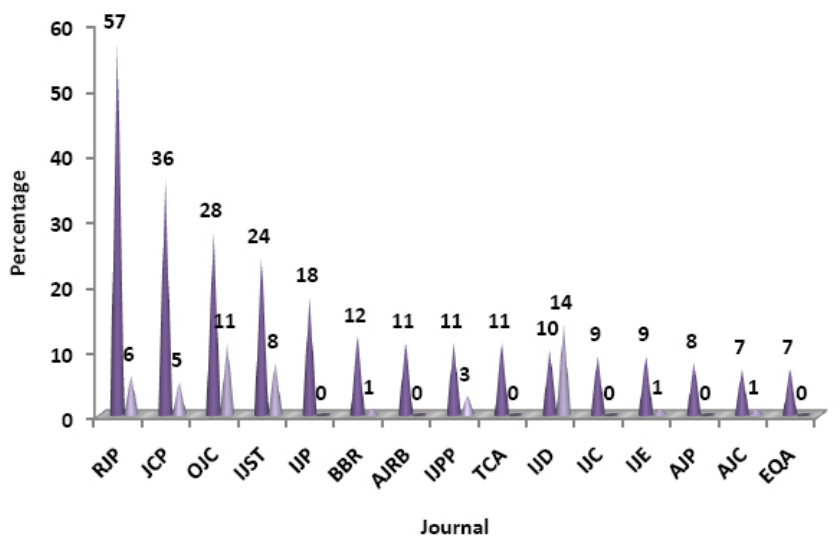

Table 6. Distribution of document type

\begin{tabular}{|c|c|c|c|c|c|}
\hline S. No. & Document Type & Articles & $\%$ & Citation & $\%$ \\
\hline 1 & Research Article & 357 & 92.25 & 73 & 84.89 \\
\hline 2 & Review Article & 18 & 4.65 & 11 & 12.79 \\
\hline 3 & $\begin{array}{c}\text { Short } \\
\text { Communication }\end{array}$ & 4 & 1.03 & 1 & 1.16 \\
\hline 4 & Editorial & 4 & 1.03 & 1 & 1.16 \\
\hline 5 & Research Note & 3 & 0.78 & 0 & 0 \\
\hline 6 & Case Study & 1 & 0.26 & 0 & 0 \\
\hline & Total & 387 & 100 & 86 & 100 \\
\hline
\end{tabular}

The above table expresses the distribution of document type based on the articles published from Lovely Professional University. It shows among the 387 articles, which includes 357 (92.25\%) Research Articles, 18 (4.65\%) Review Articles and 4 (3.38\%) Short Communication and Editorial type. Among the 86 Citations, which include 73 (84.89\%) Research Articles type followed by 11 (12.79\%) Review article type it is concluded that the highest articles and citations are from research article type of documents. 


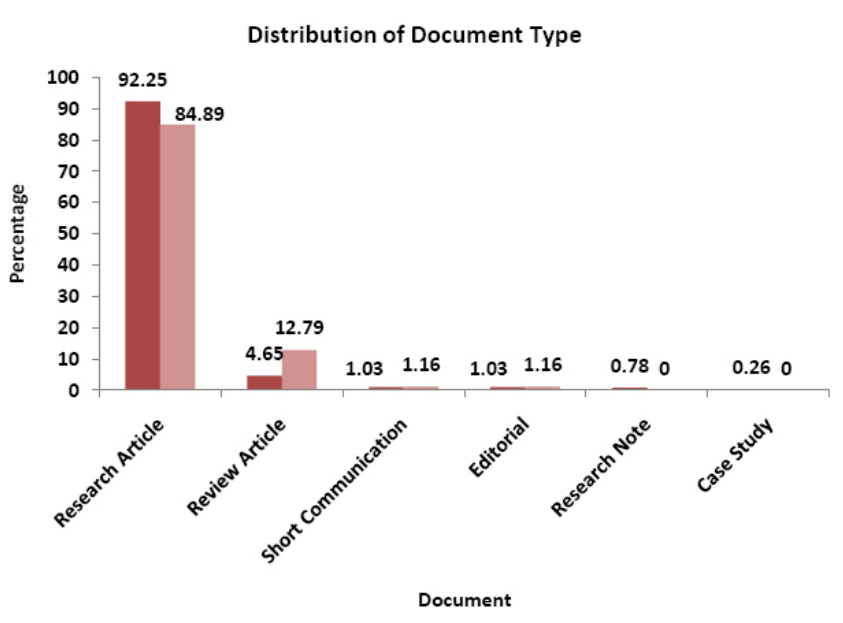

\section{Conclusion}

Indian Citation Index is a user friendly, authentic citation database to users. During the study period among the published articles 387, maximum of 148 (38.24\%) articles published in 2015 and minimum $1(0.26 \%)$ article published in 2007. Based on the citation during the period 86 citations were made. Maximum of 20 (23.26\%) citations in 2010 and 2015 followed by 19 (22.09\%) citations in 2012 was identified. The cited articles study reveals that the maximum of 15 (30.61\%) in 2015 followed by 10 (20.41\%) cited articles in 2012 . The cited density study shows that during the period maximum of 1 in 2007 and followed by 0.217 in 2010, was identified. The Author Wise Distribution of Articles and Citations study tells that the author Prasad Dwarika occupied the first position with 15 articles and 3 citations followed by author Kumar Ashish in the second position with 14 articles and 3 citations and Kumar Arun in the third position with 10 articles and 1 citation. In the case of highest citations Pramanik Tanay is in the first position with 7 citations and Singh Simranjeet occupies the second position with 4 citations. The Subject wise distribution of articles study reveals that 140 articles from Pharmacology and Pharmaceutical Science is in the first rank, 116 articles from Chemistry with second rank and 95 articles from Biological Science subject in third rank were identified. It is revealed from the study that Pharmacology and Pharmaceutical Science subject has the highest citations 42 when comparing to other subjects.. The Distribution of Top 15 Cited Journals depicts that, the Research Journal of
Pharmaceutical, Biological, and Chemical Sciences occupies the first place with 57 articles followed by the Journal of Chemical and Pharmaceutical Research with 36 articles and the third place in Oriental Journal of Chemistry with 28 articles publications. Based on the citation International Journal of Drug Development and Research occupies the first position with 14 citations and Oriental Journal of Chemistry is in the second position with 12 citations. The distribution of document type study proves that 357 (92.25\%) from Research Articles followed by 18 (4.65\%) Review Articles and 4 (3.38\%) Short Communication and Editorial type. Among the 86 Citations, 73 (84.89\%) are Research Articles type followed by 11 (12.79\%) Review article type. It is concluded that the highest articles and citations are from research article type of documents.

\section{References}

1. David N, Maureen R. Literature and bibliometrics. London: Clive Bingley; 1978.

2. Potter WG. Introduction to bibliometrics. Library Trends. 1981; 30(5). Available from: http://www.myjurnal.my/filebank/published_article /17760/4.pdf

3. Mooghali A, et al. Scientometric analysis of the scientometric literature. International Journal of Information Science and Management. 2011; 9(1).

4. Karpagam R, et al. Mapping of nano science and nanotechnology research in India: A scientometric analysis, 1990-2009. Scientometrics. 2011; 89(2):501-22.

5. Giovanni A. National research assessment exercises: A comparison of peer review and bibliometrics rankings. Scientometrics. 2011; 89(3):929-41.

6. Lapon-Kandelshein E, Prebor G. Bibliographical research in the study of Hebrew printing: A bibliometric analysis. Scientometrics. 2011; 88(3):899-913.

7. Krampen G, Eye A, Schui G. Forecasting trends of development of psychology from a bibliometric perspective. Scientometrics. 2011; 87(3):687-94.

8. Kumar S, Tiwari C, Mahija D. Contribution to Indian sociology: A bibliometric study. Language in India; 2012.

9. Dhanavandan S, Tamizhchelvan M. Citations and self citations of Indian authors in library and information science: A study based Indian Citation Index (ICI). International Journal of Academic Library and Information Science. 2014; 2(9):138-44.

10. Available from: http//www.indiancitationindex.com 